\title{
Relationship of IL-6 Level and Lipid Profile as Predictor Ventilator-Associated Pneumonia
}

\author{
Taufiq Gemawan $^{1}$, Arie Utariani², Kuntaman ${ }^{3}$ \\ ${ }^{1}$ Resident of Department of Anesthesiology and Intensive Care, Faculty of Medicine, Airlangga University-Dr \\ Soetomo General Hospital, Mayjend Moestopo Street No. 6-8, Gubeng, Surabaya, East Java 60285, Indonesia, \\ ${ }^{2}$ Staff of Department of Anesthesiology and Intensive Care, Faculty of Medicine, Airlangga University-Dr Soetomo \\ General Hospital, Mayjend Moestopo Street No. 6-8, Gubeng, Surabaya, East Java 60285, Indonesia, ${ }^{3}$ Staff of \\ Department of Clinical Microbiology, Faculty of Medicine, Airlangga University-Dr Soetomo General Hospital, \\ Mayjend Moestopo Street No. 6-8, Gubeng, Surabaya, East Java 60285, Indonesia
}

\begin{abstract}
Background: Respiration support by mechanical ventilation is an important aspect in intensive care. However, it could induce complication as infection. Ventilator Associated Pneumonia (VAP) is the most common infection in patient with ventilator support. This infection have an impact to patient's length of stay and prognosis. VAP will be followed with inflamatory responses consist of elevation IL-6 level and lipid profile abnormality. Therefore objective evaluation for acute inflamation could be a tool to diagnose VAP early.
\end{abstract}

Method: This study is analitic observational with prospektif design, to know the relationship of IL-6 dan lipid profile (HDL and LDL) toward VAP incidence in 38 patient under Intensive Care treatment. Subject observed for 7 days and IL-6, HDL,LDL levels were examined in the day with ventilator and 48 hours after it.

Result: VAP occur in 23 subject $(65,53 \%)$ from all population. IL-6 (1), IL-6(2) and $\Delta$ IL-6 levels have significant effect to VAP incidence. HDL (1), HDL (2), LDL (1), and LDL (2) levels have significant effect to VAP group. And $\triangle \mathrm{HDL}$ and $\Delta \mathrm{LDL}$ levels have significant effect to both group, VAP and non-VAP subjects.

Conclusion: IL-6, HDL and LDL level change have relation as predictor VAP incidence.

Keywords: Ventilator, IL-6, $H D L, L D L, V A P$.

\section{Introduction}

Ventilator Associated Pneumonia (VAP) is an infection that often occurs in patients using mechanical ventilators. VAP could lengthening of the patient's stay in the ICU as well as worsen the prognosis ${ }^{1}$. VAP is the second most common nosocomial infection and

\section{Corresponding Author:}

\section{Arie Utariani}

Staff of Department of Anesthesiology and Intensive Care, Faculty of Medicine, Airlangga University-Dr Soetomo General Hospital, Mayjend Moestopo Street No. 6-8, Gubeng, Surabaya, East Java 60285, Indonesia the first cause of death from nosocomial infections in critically ill patients. It incidence ranges from 5\% to $67 \%$ of cases, and most of areimmuno compromised patients, postoperatively and geriatric patients. In USA, the incidence of VAP ranges from 2 to 16 episodes every 1000 days on the ventilator ${ }^{2}$.

VAP is a lung infection, which will trigger inflammatory responses. Although VAP occurs without complications, smaller inflammatory reactions are triggered. Inflammatory responses due to infection are associated with increased levels of cytokines, including Interleukin-6 (IL-6) and Interleukin-8 (IL-8). IL-6 is a synthetic protein that induces acute phase hormones by the liver ${ }^{3,4}$. 
Changes in the lipid profile are influenced by changes in lipid metabolism in patients with acute inflammation that are related to the severity of the underlying disease in the patient ${ }^{5}$. In infections, lipopolysaccharides (LPS) and pathogenic fats are covered by HDL-C (High Density Lipoprotein), LDL (Low Density Lipoprotein) and Very Low Density Lipoprotein. And, HDL-C in particular has the highest affinity for LPS $^{6}$. Interleukin 6, along with several other cytokines also influence HDL levels through modification of triglycerides lipase. It shows that pro-inflammatory cytokines play a role in inhibiting the activity of lipoprotein lipase (LPL) and increasing the activity of Endothelial Lipase (EL), both of which are associated with low HDL levels during acute or chronic inflammatory inflammation ${ }^{7}$. Endothelial lipase (EL) is known as a member of the lipoprotein lipase gene family which is hydrolyzes HDL phospholipids and reduce HDL cholesterol level. Therefore, inhibition of EL can increase HDL. And EL is one of the important enzymes in the regulation of HDL metabolic physiology ${ }^{8}$.

This study is aimed to find an association between IL-6 and lipid profile as predictors of VAP events.

\section{Material and Method}

This study was an observational analytic with a prospective design, to determine the relationship of IL-6 levels and lipid profiles (HDL and LDL) as predictors of VAP incidence. It conducted at Regional Hospital in Indonesia from January to April 2020. All patient met inclusion criteria were observed daily for signs and symptoms of VAP according CDC diagnose criteria 2010. There are two point of profile lipid and IL-6 examination. The first is after intubation and ventilator support and the second is after 2 days of ventilator support. All patient observed for day- 1 to day-8.

\section{Results and Discussion}

This study was approved by the Research Ethics Committee of the RSUD Dr. Soetomo Surabaya.There are 37 patients met the study inclusion and exclusion criteria. All subject charateristics and diagnose are decribed in table 1.

This study shows there are 23 patient diagnosed for VAP $(60,53 \%)$ from study population. It consist of 18 male and 5 female. These VAP patient are treated in ICU (5 patients), Resucitation Room (RES) (3 patients) and Intermediet Observation Room (ROI) (15 patients).

Table 1. Subject Characteristics

\begin{tabular}{|c|c|c|c|c|c|}
\hline & \multicolumn{2}{|c|}{ VAP } & \multirow{2}{*}{ Total } & \multirow{2}{*}{$P$ value } & \multirow{2}{*}{ RR (CI95\%) } \\
\hline & Yes $(n=22)$ & No $(n=15)$ & & & \\
\hline \multicolumn{4}{|l|}{ Gender } & \multirow{3}{*}{0,157} & \multirow{3}{*}{$1,66(0,81-3,4)$} \\
\hline Male & $18(69,2 \%)$ & $8(30,8 \%)$ & 26 & & \\
\hline Female & $5(41,7 \%)$ & $7(58,3 \%)$ & 12 & & \\
\hline \multicolumn{6}{|l|}{ Unit } \\
\hline ICU & $5(71,4 \%)$ & $2(28,6 \%)$ & 7 & & \\
\hline RES & $3(33,3 \%)$ & $6(66,7 \%)$ & 9 & & \\
\hline ROI & $15(68,2 \%)$ & $7(31,8 \%)$ & 22 & & \\
\hline \multicolumn{6}{|l|}{ Age } \\
\hline Mean \pm SD & $49,8 \pm 11,2$ & $43,5 \pm 11,9$ & $47,3 \pm 11,76$ & 0,114 & $1,05(0,49-1,12)$ \\
\hline \multicolumn{6}{|l|}{ Diagnose } \\
\hline Perforated Appendicitis & & & 1 & & \\
\hline Hematothorax & & & 1 & & \\
\hline Metabolic Acidosis+ CKD & & & 3 & & \\
\hline Pulmonary Edema + CKD & & & 4 & & \\
\hline Severe Brain Injury & & & 4 & & \\
\hline Coronary Artery Disease & & & 2 & & \\
\hline
\end{tabular}




\begin{tabular}{|l|l|l|l|l|l|}
\hline \multirow{2}{*}{} & \multicolumn{2}{|c|}{ VAP } & \multirow{2}{*}{ Total } & \multirow{2}{*}{ P value } & \multirow{2}{*}{ RR (CI95\%) } \\
\cline { 2 - 5 } & Yes (n=22) & No (n=15) & & \\
\hline Pulmonary edema+ Eclampsia & & & 7 & & \\
\hline Intra Cerebral Hematoma & & & 3 & & \\
\hline Severe Pre-eclampsia & & & 4 & & \\
\hline Myastenia Gravis & & & 2 & & \\
\hline Guillen-Barre Syndrome & & & 2 & & \\
\hline Phlegmon & & & & & \\
\hline Peritonitis & & & & \\
\hline
\end{tabular}

The difference value $(\Delta)$ of IL-6 obtained $18.9 \mathrm{ng} / \mathrm{L}$ $(1.8-188.5 \mathrm{ng} / \mathrm{L})$ in the VAP case and $\Delta$ IL-6 value was $-1.6 \mathrm{ng} / \mathrm{L}(-22.9-1 \mathrm{ng} / \mathrm{L})$ in non-VAP cases (p value $<0,0001)$ with a correlation coefficient of 1,000 . The $\Delta$ HDL values obtained $-19 \mathrm{mg} / \mathrm{dL}(-32-(-5) \mathrm{mg} / \mathrm{dL})$ in VAP cases and $\Delta \mathrm{HDL}$ values of $-1 \mathrm{mg} / \mathrm{dL}(-2-2 \mathrm{mg} /$
$\mathrm{dL}$ )( $\mathrm{p}$ values $<0,0001$ ) with a correlation coefficient of 1,000 . The $\Delta \mathrm{LDL}$ value is $-27 \mathrm{mg} / \mathrm{dL}(-61-(-11) \mathrm{mg} / \mathrm{dL})$ in the VAP case and the $\Delta$ LDL value is $-1 \mathrm{mg} / \mathrm{dL}(-3-3$ $\mathrm{mg} / \mathrm{dL}$ ) ( $\mathrm{p}$ value $<0,0001$ ) with a correlation coefficient of 1,000 . All of these value described in table 2 .

Table 2. Relationship of different value ( $\Delta$ ) IL-6, HDL, LDL with VAP incidence

\begin{tabular}{|l|c|c|c|c|c|}
\hline \multirow{2}{*}{ Nilai $\Delta$} & \multicolumn{2}{|c|}{ Kejadian VAP } & \multirow{2}{*}{ Nilai p } & \multirow{2}{*}{ Koefisien Korelasi } & \multirow{2}{*}{ RR (CI 95\%) } \\
\cline { 2 - 3 } & Ya & Tidak & $<0,0001$ & 1,000 & NA \\
\hline IL-6 & $18,9(1,8-188,5)$ & $-1,6(-22,9-1)$ & $<0,0001$ & 1,000 & NA \\
\hline HDL & $-19(-32-(-5))$ & $-1(-2-2)$ & $<0,0001$ & 1,000 & NA \\
\hline
\end{tabular}

As described earlier, in this study we examine two times, first we do ata the first time patient supported with ventilator(value 1) and the the second is when patients already supported by ventilaor for two days (value 2). The value of of these examination described in table 3 .

Table 3. Relationship between IL-6, HDL, and LDL value with VAP incidence

\begin{tabular}{|l|c|c|c|}
\hline & Nilai 1 $^{\mathbf{a}}$ & Nilai 2 $^{\mathbf{b}}$ & Nilai p \\
\hline \multicolumn{5}{|l|}{ VAP (+) } & $14,25(2,3-35)$ & $42,4(6,1-202,7)$ & $<0,0001^{*}$ \\
\hline IL-6 & $35(16-52)$ & $12(7-31)$ & $<0,0001^{*}$ \\
\hline HDL & $80(43-98)$ & $47(14-79)$ & $<0,0001^{*}$ \\
\hline LDL & $51,8(11,1-92,30)$ & $41,20(10,7-92,0)$ & $0,003^{*}$ \\
\hline VAP (-) & $51(13-54)$ & $52(12-54)$ & 0,08 \\
\hline IL-6 & $93(42-98)$ & $93(42-96)$ & 0,273 \\
\hline HDL &
\end{tabular}

a. examintaion at the first time supported by ventilator, ${ }^{\text {b. }}$ examination after 2 days of ventilator support 
VAP in patients, especially critically ill patients, is a disadvantage. This will worsen patient's prognosis and increase his morbidity and mortality. Early recognition and detection in critically ill patients can reduce the riskto VAP incidence. In Intensive Care Unit (ICU), The observations of VAP signs and symptoms are carried out routinely especially when the ventilator is used for more than 48 hours or 2 days. Therefore, VAP condition can be recognized early to prevent further complications which will worsen patient's critical condition. However, it implementations become difficult due to the severity of patient's condition in the ICU. Therefore, we need an objective sign that helps in establishing the diagnosis of VAP in patients at risk. In this research, HDL and LDL and IL-6 levels were used as markers for the VAP incidence.

In prospective study of 44 ventilated patient, it is concluded that IL- 6 values are significantly different cytokines in patients with confirmed VAP compared to other types of cytokines. In addition IL- 6 was found as a fairly high risk predictor of VAP with a high sensitivity and specificity value ${ }^{4}$. In a retrospective study, it was found that IL- 6 values of more than $100 \mathrm{pg} / \mathrm{mL}$ on the first day of patients on ventilator were predictive for infectious complications in patients with ventilators, mainly lung infections and associated with increased mortality. This is related to the inflammatory response to the course of infection that begins to arise which in this case is a complication of infection due to ventilator or $\mathrm{VAP}^{9}$.

Interleukin 6, along with several other cytokines also influence HDL levels through modification of triglycerides lipase. It shows that pro-inflammatory cytokines play a role in inhibiting the activity of lipoprotein lipase (LPL) and increasing the activity of endothelial lipase (EL), both of these are associated with low HDL levels during acute or chronic inflammation ${ }^{7}$. Endothelial lipase (EL) is known as a member of the lipoprotein lipase gene family which is hydrolyzes HDL phospholipids and lowers HDL cholesterol level. So that inhibition of EL could increase HDL and EL is one of the important enzymes in the regulation of HDL metabolic physiology ${ }^{8}$. In serum, LPS which is an endotoxin in gram-negative bacteria is predominantly bound to VLDL and LDL, via LDL receptors. This results in inactivation of LPS. Then LPS is quickly taken by hepatocytes to be delivered into peripheral cells ${ }^{10}$.

\section{Conclusion}

This study found that the examination of IL-6, HDL and HDL have potential as predictor of VAP incidence, so serial examination of these biomarker could detect VAP earlier to minimize it's complication and improve patient prognosis.

Acknowledgements: We sincerely thanks to all patients of ICU unit for the participation in this research and all co-author, lecturers and staff for all advice and guidance for this paper.

Conflict of Interest: The authors declare that there is no conflict of interest for this research.

Source of Funding: The authors received no financial support for the research, authorship, and/or publication of this article.

Ethical Clearance: This research is approved by Health Research Ethical Committee Soetomo Teaching Hospital Surabaya.

\section{References}

1. Karatas M, Saylan S, Kostakoglu U, Yilmaz G. An assessment of ventilator-associated pneumonias and risk factors identified in the Intensive Care Unit. Pak J Med Sci. 2016 Jul-Aug;32(4):817-22. doi: $10.12669 /$ pjms.324.10381.

2. Timsit JF, Esaied W, Neuville M, Bouadma L, Mourvllier B. Update on ventilator-associated pneumonia. F1000Res. 2017 Nov 29;6:2061. doi: 10.12688/f1000research.12222.1

3. Bonten MJ, Froon AH, Gaillard CA, Greve JW, de Leeuw PW, Drent M, Stobberingh EE, Buurman WA. The systemic inflammatory response in the development of ventilator-associated pneumonia. Am J Respir Crit Care Med. 1997 Oct;156(4 Pt 1):1105-13. doi: 10.1164/ajrccm.156.4.9610002.

4. Ramírez P, Ferrer M, Gimeno R, Tormo S, Valencia M, Piñer R, Menendez R, Torres A. Systemic inflammatory response and increased risk for ventilator-associated pneumonia: a preliminary study. Crit Care Med. 2009 May;37(5):1691-5. doi: 10.1097/CCM.0b013e31819fec5f.

5. Khovidhunkit, W, Memon R, Feingold K, Grunfeld C. Infection and Inflammation-Induced Proatherogenic ChangesofLipoproteins. TheJournal of Infectious Diseases. 2000;181(s3):S462-S472. 
6. Cirstea M, Walley KR, Russell JA, Brunham LR, Genga KR, Boyd JH. Decreased high-density lipoprotein cholesterol level is an early prognostic marker for organ dysfunction and death in patients with suspected sepsis. J Crit Care. 2017 Apr;38:289294. doi: 10.1016/j.jcrc.2016.11.041..

7. Zuliani G, Volpato S, Blè A, Bandinelli S, Corsi AM, Lauretani F, Paolisso G, Fellin R, Ferrucci L. High interleukin- 6 plasma levels are associated with low HDL-C levels in community-dwelling older adults: the InChianti study. Atherosclerosis. 2007 Jun;192(2):384-90. doi: 10.1016/j. atherosclerosis.2006.05.024.

8. Jin W, Millar JS, Broedl U, Glick JM, Rader DJ. Inhibition of endothelial lipase causes increased
HDL cholesterol levels in vivo. J Clin Invest. 2003 Feb;111(3):357-62. doi: 10.1172/JCI16146.

9. Woiciechowsky C, Schöning B, Cobanov J, Lanksch WR, Volk HD, Döcke WD. Early IL-6 plasma concentrations correlate with severity of brain injury and pneumonia in brain-injured patients. J Trauma. 2002 Feb;52(2):339-45. doi: 10.1097/00005373-200202000-00021.

10. Topchiy E, Cirstea M, Kong HJ, Boyd JH, Wang Y, Russell JA, Walley KR. Lipopolysaccharide Is Cleared from the Circulation by Hepatocytes via the Low Density Lipoprotein Receptor. PLoS One. 2016 May 12;11(5):e0155030. doi: 10.1371/ journal.pone. 0155030 . 